\title{
Reducing Stormwater Runoff from Parking Lot with Permeable Pavement
}

\author{
Suripin Suripin ${ }^{1 *}$, Sri Sangkawati Sachro ${ }^{1}$, Pranoto Samto Atmojo ${ }^{1}$, Sutarto Edhisono ${ }^{1}$, Hary Budieny ${ }^{1}$, and Dwi Kurniani ${ }^{1}$ \\ ${ }^{1}$ Civil Engineering Department, Faculty of Engineering, Diponegoro University, Semarang - Indonesia
}

\begin{abstract}
Increased urbanization has an impact on increased impervious surface, consequently the urban drainage system becomes gradually overloaded, with frequent spills and inundate urban areas. Upgrade or re-design the existing drainage system is not an effective solution because it does not address the source of the problem. It is necessary strategies for urbanization reduction of storm-water runoff. These strategies are aimed to reduce storm-water runoff mainly through water infiltration. One of the strategies is to develop permeable pavement. This study is aimed to test the capacity of permeable pavement through the development of full scale physical models in the parking lot. The results show that proposed permeable pavement are able to significantly reduce volume and peak discharge of storm-water runoff, delay the start of runoff and slow the peak discharge. The application of this proposed permeable pavement in the urban area is strongly recommended to reduce drainage load as well as to increase groundwater recharge.
\end{abstract}

Keywords: urbanization, urban drainage, stormwater runoff, permeable pavement.

\section{1 introduction}

Urbanization over the last three decades has increased rapidly in several cities in Indonesia, in line with population growth and economic growth. The land cover changed from open land to build land is inevitable. Road pavement and other impermeable surfaces associated with vehicle movement, including driveways and parking lots contribute up to $70 \%$ of urban impermeable land, all of which are sources increasing drainage load. This has had a considerable impact on natural surface runoff and local hydrological behaviour. Evapotranspiration and interception decreased after trees and other plants were cleared in the process of land development. Infiltration is decreased, concentration time is shortened, and consequently the peak discharge can multiply. Most of the rain water is thrown out through urban drainage system and finally to the river. River flows become very high in the rainy season, resulting in frequent floods. By contrast, rivers are almost dry in the dry season, due to the very small base flow [1].

Increased capacity of urban drainage system and / or river will not be effective, as it does not address the source of the problem. The increase in drainage load will continue to occur as urbanization continues for some time. Therefore a strategy that is able to restore the natural function of the land in redistributing rainwater, especially to infiltrate and restore storm water is needed. One of the strategies is developing permeable pavement. Comparing to other strategies, permeable pavements are highly effective and easily applicable [2]. Paving block pavement is a permeable pavement that has been widely known in Indonesia. Most parking lot in Indonesia is constructed using paving block pavement.

Unfortunately, many cases are found in the field, the construction of permeable pavement which is not in accordance with the main purpose of constructing permeable pavement, i.e. to reduce surface runoff, or in other words to increase the capacity of retention and infiltration. The pavement layer (top layer) is composed of paving blocks, but the underlying structure does not match the permeable pavement structure. For example permeable pavement built on clay soil layer by simply compacting the original soil, layering $5-10 \mathrm{~cm}$ of sand and paving block installed on it. Even in some cases, permeable pavement found on non-permeable pavement only by layering $5-10 \mathrm{~cm}$ of sand and above it installed paving blocks without removing non-permeable layers that previously existed. Paving blocks used are also not paving blocks that have a high porosity, but semiimpermeable paving block. In addition to increasing groundwater recharging, the purpose of permeable pavement construction is to improve the quality of surface runoff that will infiltrate into the soil through filtration. This paper discusses the model of permeable pavement structures for parking lots capable of reducing storm water runoff even to zero surface runoff.

The general principle of permeable pavement is simply to infiltrate storm water runoff to support groundwater recharge. Storm water retention and infiltration by means of permeable pavement is a sustainable and cost effective process, which is suitable for urban drainage system $[3,4]$. It is also has many

* Corresponding author: suripin.ar@gmail.com 
potential benefits such as reduction of runoff, augmenting groundwater, prevention of water pollution [5]. The permeable pavement model is designed based on the water balance equation proposed by Smith [6]. Based on Fig. 1, the depth of the absorption structure can be formulated as follows:

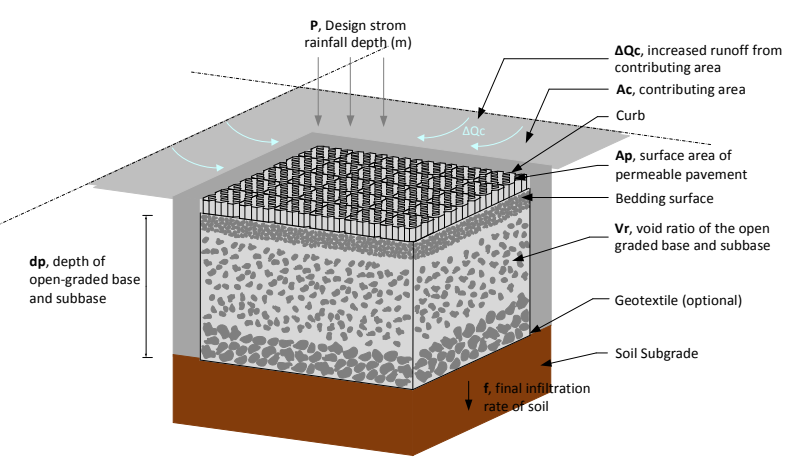

Fig. 1. Structure of Permeable Pavement [6]

$$
\begin{gathered}
V_{w}=\Delta Q_{n} A_{n}+P A_{p}-f T A_{p} \\
V_{p}=\frac{V_{w}}{V_{r}}=d_{p} A_{p}(2)
\end{gathered}
$$

where: $\mathrm{V}_{\mathrm{w}}$ is the water volume, $\mathrm{m}^{3} ; \Delta \mathrm{Q}$ : addition of discharge from catchment area, $\mathrm{m} ; \mathrm{A}_{\mathrm{c}}$ : area of water catchment, $\mathrm{m}^{2}$; P: rainfall depth, $\mathrm{m} ; \mathrm{A}_{\mathrm{p}}$ : surface area of permeable pavement, $\mathrm{m}^{2}$; f: infiltration rate of native soil (base soil), $\mathrm{m} /$ hour; $\mathrm{T}$ : the effective filling time of the base, hours (typically 2 hours); $\mathrm{V}_{\mathrm{r}}$ : void ratio of pavement filler material (base); and $d_{p}$ : the base depth, m.

The combination of equations (1) and (2) yields the following relationships:

$$
\mathrm{d}_{\mathrm{p}} \mathrm{A}_{\mathrm{p}} \mathrm{V}_{\mathrm{r}}=\Delta \mathrm{Q}_{\mathrm{c}} \mathrm{A}_{\mathrm{c}}+\mathrm{PA}_{\mathrm{p}}-\mathrm{fTA}_{\mathrm{p}} \text { (3) }
$$

The surface area of permeable pavement $\left(A_{p}\right)$ and base depth $\left(d_{p}\right)$ can be formulated as the following demands while providing a hard surface, which can be utilized in urban areas $[6,7]$.

\section{Materials and Equipment}

The permeable pavement model was developed in the parking lot of the Civil Engineering Department of Diponegoro University, Semarang Indonesia. The existing conventional paving block pavement cannot manage storm water, so when there is heavy rain there is always an inundation on the surface of the pavement. Inundation may last more than 1 day (24 hours). Paving blocks used in the form of cubes with the size of $21 \mathrm{~cm}$ long, $10.5 \mathrm{~cm}$ wide, and $6 \mathrm{~cm}$ thick. The porosity of the paving block is low, and the installation is very tight, there is no gap between the paving. Consequently the rain water is difficult to penetrate the paving block surface. The pavement paving block structure is composed of a layer of paving block laid down on a 5-10 $\mathrm{cm}$ thick layer of sand that is spread directly over a compacted clay base. Therefore the capacities in storing water as well as the infiltration capacity are low.

The proposed permeable pavement model is constructed in the form of model with a length of $240 \mathrm{~cm}$ and a width of $150 \mathrm{~cm}$ (Fig. 2). The fundamental difference between conventional permeable pavement, here and after called paving block pavement (PBP), and proposed permeable pavement, here and after called permeable paving block pavement (P2BP) is the presence of voids in permeable pavement, including the pavement surface, which reduces imperviousness and allows storm water to infiltrate into and through the pavement [8]. The general structure of P2BP consists of several layers, covering a surface layer of permeable paving concrete, arranged manually on a layer of sand, and a layer of gravel. The characteristics and thickness

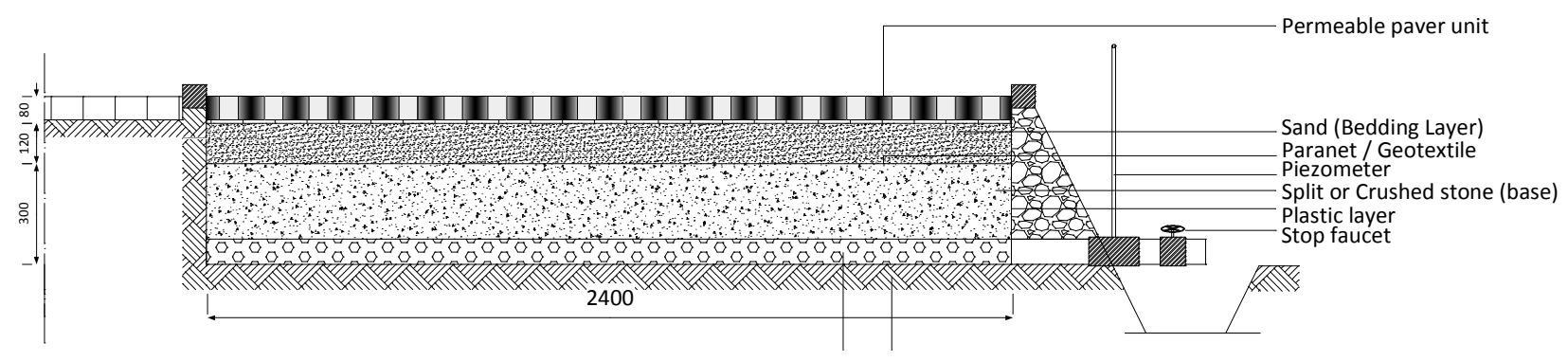

Fig.2. The proposed Permeable Paving Block Pavement (P2BP)

equation:

$$
\begin{gathered}
A_{p}=\frac{\Delta Q_{c} A_{c}}{V_{r} d_{p}-p^{p}+[}(4) \\
d_{p}=\frac{\Delta Q_{c} R+P-E T}{V_{T}} ; R=\frac{A_{C}}{A_{p}}(5)
\end{gathered}
$$

where $\mathrm{R}$ is the ratio between the water catchment area and the surface area of the permeable pavement.

Matters to be considered in permeable pavement design is that the paving block must have a high porosity to ensure surface runoff can be infiltrate freely, as well as its base as a reservoir must have a high porosity that can hold a lot of water. They should meet storm water of each material depends on the size of the discharge to be managed [9].

Concrete paving block used in the model is grade paver type, with size $40 \mathrm{~cm}$ long, $30 \mathrm{~cm}$ wide, and $8 \mathrm{~cm}$ thick. The ratio between the holes area to the total surface area of paving is approximately $40 \%$. The high porosity of paving is needed to guarantee a good infiltration and air exchange rates [3]. Open graded material consists of 2 types, coarse sand and crushed stone. Coarse sand is used for the base of installation of concrete pavers. While crushed stone serves as a water reservoir consisting of crushed stone ranges in size from 19 to $63 \mathrm{~mm}$ and porosity ranges from 35 to $45 \%$. The 
fine material through which the water flows tends to carry and fill the pores of the rougher material. To reduce this action, a separation layer such as geotextile or the like is required as a filter. This filter is used to separate between crushed stone and sand layer.

\section{Results and Discussion}

Permeable pavement must be designed to be able to absorb rain water as much as possible, for that they must have high porosity, enough space to hold water, and able to pass water and air easily. Infiltration should be fast enough to avoid the possibility of significant ponding for any event of rain, including rainfall design.

\subsection{Design Model of Permeable Pavement}

The depth of the model is designed based on the design rain with the 25 year return period in the region of Semarang City. Taking into account the effects of climate change on rainfall characteristics, the design rainfall is $245 \mathrm{~mm}$ [10]. Soil permeability was obtained both from laboratory analysis and field infiltration test. Laboratory analyses found that the soil permeability is $17.64 \mathrm{~mm} /$ hour, while infiltration test gave slightly lower, as shown in Fig. 3. Similar results were obtained in previous studies with adjacent sites [11].

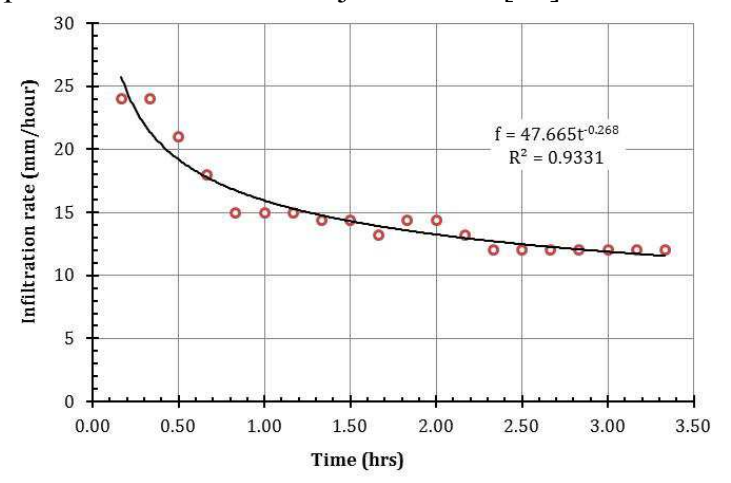

Fig. 3. Infiltration rate based on the field measurement using infiltrometer

Based on the above data and characteristics, the base depth of permeable paving block pavement (P2BP) can be estimated by using equation (5).

The overall dimension of the P2BP model is as follows (refer to Fig.2): length $240 \mathrm{~cm}$; width $150 \mathrm{~cm}$; base depth $42 \mathrm{~cm}$, composed of two layer: gravel and sand; open graded base reservoir: gravel $30 \mathrm{~cm}$; open graded bedding coarse: sand $12 \mathrm{~cm}$; concrete permeable pavers $8 \mathrm{~cm}$. Rainfall simulator was used to generate design rainfall. Depth, duration, and intensity of rainfall were observed.

\subsection{Storm water Runoff}

The primary role of a permeable pavement is to reduce storm-water runoff volume and promote hydrograph attenuation. Two scenarios were made, ie.: full exfiltration model and partial exfiltration. Full exfiltration means the water infiltrates directly into the base and exfiltrates to the soil. This is the most common application. While partial exfiltration does not rely completely on exfiltration of the base into the soil to dispose of all the captured runoff. Some of the water may exfiltrates into the soil while the remainder is drained by perforated pipes.

In the full exfiltration scenario, the observations were made by measuring the water level in the piezometer mounted at the perforated pipe close to the outfall (see Fig.2). Two different rainfall intensity, rainfall depth, and rainfall duration (Table 1) were observed. The water depth in the storage (base) can be predicted by balancing between cumulative rainfall depth, storage capacity and cumulative infiltration. The results are presented graphically in Fig. 4. The results show that for rainfall intensity up to $90 \mathrm{~mm} /$ hour there is no occurs until rainfall lasts 2.5 hours, meanwhile for rainfall intensity of $137 \mathrm{~mm} /$ hour surface runoff occurred after rainfall lasted 2 hours. Based on these results, for a design rainfall $245 \mathrm{~mm}$, if the duration of rainfall longer than 2 hours will not generate surface runoff, otherwise if the duration of rainfall less than 2 hours will lead to surface runoff.

Table 1. Field measurement of full exfiltration

\begin{tabular}{|c|c|c|l|}
\hline $\begin{array}{c}\text { Experi- } \\
\text { ment }\end{array}$ & $\begin{array}{c}\text { Rainfall } \\
\text { intensity } \\
\text { (mm/hour) }\end{array}$ & $\begin{array}{c}\text { Rainfall } \\
\text { duration } \\
\text { (hours) }\end{array}$ & \multicolumn{1}{|c|}{ Remarks } \\
\hline 1 & 90.47 & 2.5 & No overflow \\
\hline 2 & 137.68 & 2.7 & Overflow after 2 hours \\
\hline
\end{tabular}
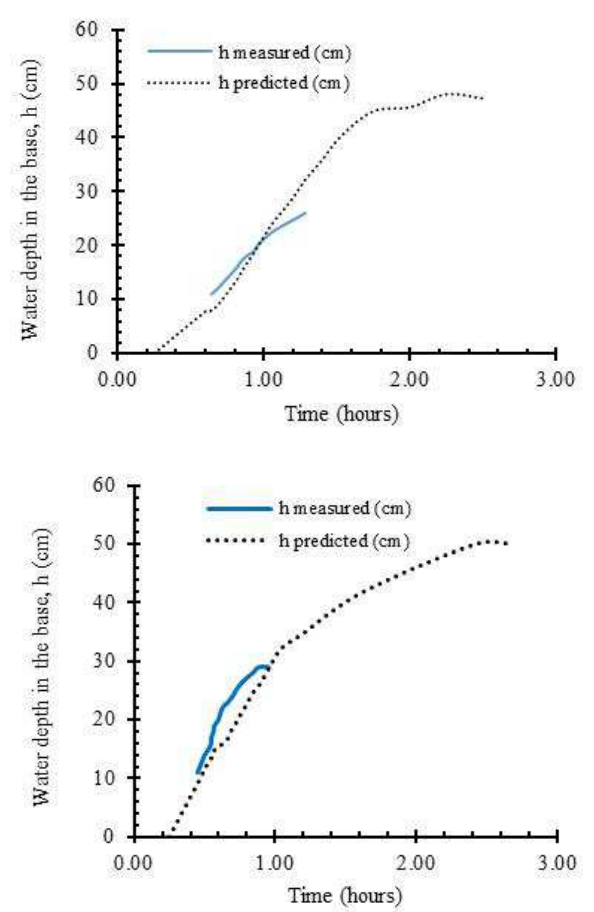

Fig. 4. Measured and predicted water depth in the storage

This result is much greater than the experiment done by Suda and Yamanaka [12]. They used a rainfall simulator over permeable interlocking concrete pavement with pervious concrete blocks found that for 
the first $30 \mathrm{~min}$ of a $50 \mathrm{~mm} / \mathrm{h}$ constant intensity rainfall, there was no runoff observed.

In the case of partial exfiltration, the water absorbed into the P2BP partially infiltrate into the soil, and the other flows out through the perforated pipe to the drainage canal. Measurements are made to the discharge coming out of P2BP, as shown in Table 2. It can be seen that volume of the storm water runoff can be reduced 33.42 to $46.05 \%$, meanwhile the peak discharge can be reduced 6.19 to $14.50 \%$. Reduction of peak discharge was smaller than previous research results, which reached $42 \%[6,13,14]$. Application of permeable pavements in Tianjin University, China indicated that it was able to decrease $35.6 \%$ of total rainfall runoff and $28.7 \%$ of peak flow [15]

Table 2. Field measurement of partial exfiltration

\begin{tabular}{|c|l|c|r|r|}
\hline \multirow{2}{*}{ No. } & \multicolumn{1}{|c|}{ Description } & \multirow{2}{*}{ Unit } & \multicolumn{2}{|c|}{ Experiments } \\
\cline { 4 - 5 } & & $\mathrm{mm} / \mathrm{hr}$ & 224.78 & 248.21 \\
\hline 1 & Rainfall intensity & liter/s & 0.2139 & 0.2360 \\
\hline 2 & $\begin{array}{l}\text { Maximum discharge of } \\
\text { conventional paving block }\end{array}$ & & & \\
\hline 3 & Rainfall volume (inflow) & liters & 310.20 & 367.60 \\
\hline 4 & Rainfall duration & hours & 0.38 & 0.41 \\
\hline 6 & Maximum outflow of P2BP & lt $/ \mathrm{s}$ & 0.2000 & 0.2000 \\
\hline 7 & Outflow volume & liters & 206.54 & 198.33 \\
\hline 8 & Percent of outflow reduction & $\%$ & 33.42 & 46.05 \\
\hline 9 & Reduction of peak discharge & $\%$ & 6.19 & 14.50 \\
\hline
\end{tabular}

The delay of the start of surface runoff and peak discharge respectively are 13 and 22 minutes (Fig. 5). In the conventional permeable pavement once it rainfall less than a minute directly surface runoff occured, and three minutes later the peak discharge has occurred. It is in line with study carried out by [16]. They used permeable pavers with dimension $2.0 \mathrm{~m}$ long by $2.0 \mathrm{~m}$ wide, with bedding aggregate $(80 \mathrm{~mm}$ and $30 \mathrm{~mm})$, permeable base $(100 \mathrm{~mm})$, and sub-base $(100 \mathrm{~mm})$. For rainfall intensities of 50,100 and $150 \mathrm{~mm} / \mathrm{h}$ found initial runoff delays of 17,10 , and 8 minutes respectively. While peak discharges occurred on 21,18 , and 16 minutes respectively. The smaller the rainfall intensity the longer the start delay of runoff and time to peak discharge tend to.

\subsection{Result Implication}

Based on the results explained above, and using equation 5, a chart can be developed to design P2BP for various conditions of natural soil type and rainfall height. Although the experiment did not include the discharge from outside the model, in other words $\Delta \mathrm{Q}$ is equal to zero, but it does not affect the equilibrium equation of water as equation 5 . On this occasion graphs are shown for 2 different types of soil: silt loam and loamy sand, each has a permeability coefficient, $\mathrm{f}=4 \times 10^{-6} \mathrm{~m} / \mathrm{s}$ $(1.44 \mathrm{~cm} / \mathrm{h})$ and $2 \times 10-5 \mathrm{~m} / \mathrm{s}(7.20 \mathrm{~cm} / \mathrm{hr})$, as can be seen in Fig. 6.
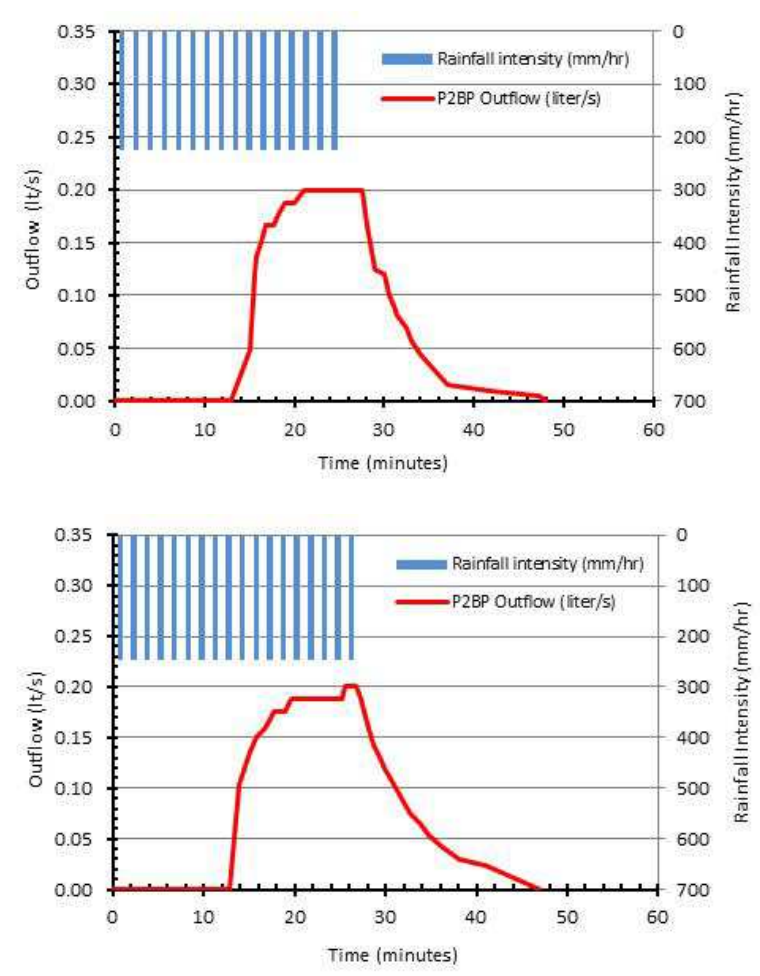

Fig. 5. Measured outflow from P2PB
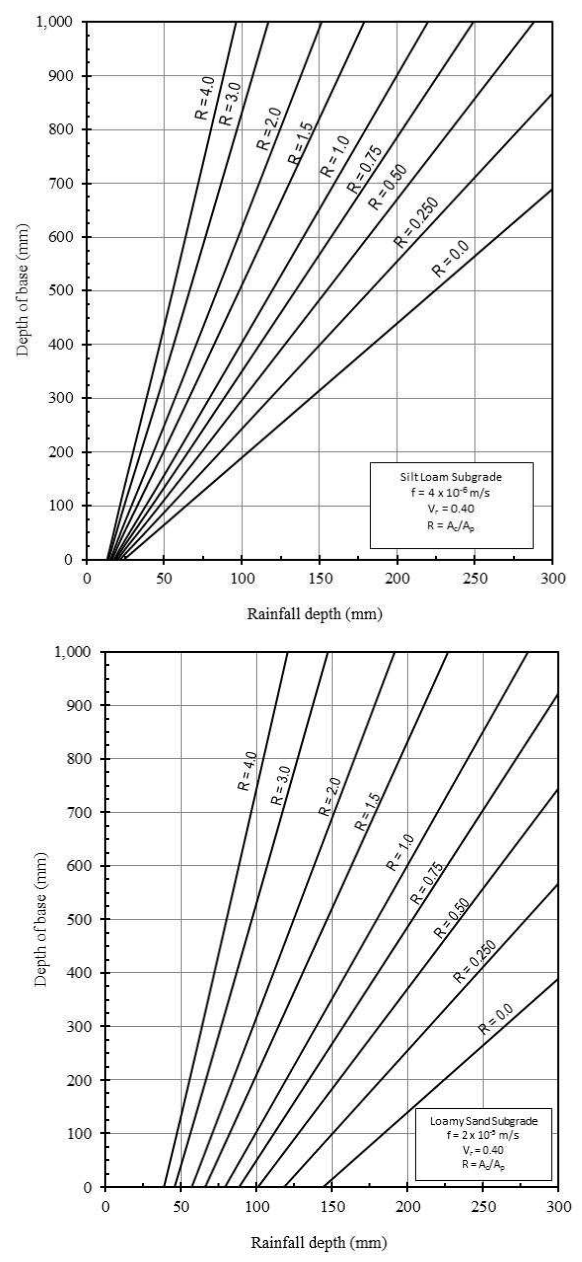

Fig. 6. Chart to design $\mathrm{P} 2 \mathrm{~PB}$ 
The use of the chart is very easy, and does not require any difficult data. Data needed are rainfall data (design rainfall), natural soil type, subgrade material to be used, and water catchment area along with its runoff coefficient $(\mathrm{CN})$. The following are examples of how to use it.

Characteristics of the conventional parking lot are as follows:

Area of parking lot

Runoff coefficient, $\mathrm{CN}$

$$
=15.000 \mathrm{~m}^{2}
$$$$
=90
$$

Design rainfall

$=200 \mathrm{~mm}$

Natural soil type: loamy sand, $f=7.20 \mathrm{~cm} / \mathrm{hr}(2 \times 10$ $5 \mathrm{~m} / \mathrm{s}$ )

The depth of the sub grade for various $\mathrm{R}$, the ratio between the water catchment area and the surface area of the permeable pavement, can be calculated based on right chart in Fig. 6. The results are presented in Table 3. When all parking lot areas are used as permeable paving block pavement (P2BP), the value of $\mathrm{R}=0$, then only the depth of base is $15 \mathrm{~cm}$, otherwise if only half of parking lot converted to $\mathrm{P} 2 \mathrm{BP}$, means $\mathrm{R}=1$, then required depth of base become $60 \mathrm{~cm}$. Even if only onethird of parking lot areas are used as P2BP, it means $\mathrm{R}=$ 2 , then the required base thickness becomes $85 \mathrm{~cm}$.

Table 3. The depth of P2BP base for various $R$

\begin{tabular}{|c|c|c|c|c|c|}
\hline No. & $\begin{array}{c}\text { Total } \\
\text { parking } \\
\text { lot area } \\
\left(\mathrm{m}^{2}\right)\end{array}$ & $\begin{array}{c}\text { Catchment } \\
\text { area, } \mathrm{A}_{\mathrm{c}} \\
\left(\mathrm{m}^{2}\right)\end{array}$ & $\begin{array}{c}\text { P2BP area, } \\
\mathrm{A}_{\mathrm{p}}\left(\mathrm{m}^{2}\right)\end{array}$ & $\mathrm{R}$ & $\begin{array}{c}\text { Depth of } \\
\text { base, } \mathrm{d}_{\mathrm{p}} \\
(\mathrm{cm})\end{array}$ \\
\hline$[1]$ & {$[2]$} & {$[3]$} & {$[4]$} & {$[5]$} & {$[6]$} \\
\hline 1 & 15,000 & 0 & 15,000 & 0.0 & 15 \\
\hline 2 & 15,000 & 5,000 & 10,000 & 0.5 & 40 \\
\hline 3 & 15,000 & 7,500 & 7,500 & 1.0 & 60 \\
\hline 4 & 15,000 & 10,000 & 5,000 & 2.0 & 85 \\
\hline
\end{tabular}

\section{Conclusions}

Development of vehicle infrastructure such as roads, parking lot, and carport impacts on storm-water redistribution. Storm-water runoff is increased, accompanied by decreased groundwater recharge. If this is not properly managed would result in urban flood disasters.

Application of permeable paving block pavement (P2BP) proved able to reduce the two negative impacts. $\mathrm{P} 2 \mathrm{BP}$ is able to decrease surface runoff volume by 33.42 to $46.05 \%$, decrease peak discharge by $\%, 6.19$ to $14.50 \%$, and delay the start of surface runoff and peak time respectively by 13 and 22 minutes.

It is recommended to do further research by making larger P2BP on different soil types. Continuous observations should be done for the development of permeable paving block pavement design guidelines.

\section{Acknowledgments}

The authors would like to thank the Institute for Research and Community Services (LPPM) of Diponegoro University for the financial support of this research. Additionally, the authors thank Legimin and Daryono for assistance with site construction and field experiments. Further thanks are extended to Saktyo Danisworo for assistance in preparing the permeable paving block model development plan and drawing.

\section{References}

1. Wong T, Breen P., and Lloyd S. CRCCH Technical Report 00/01 (2000)

2. Marchioni, M. and Becciu, G. Int. J. Sus. Dev. Plann. Vol. 10, No. 7 (2015) 806-817

3. Dierkes C, Go" bel P, Benze W, Wells J. In: Melbourne Water, editor. Proceedings of the $2^{\text {nd }}$ national conference on water sensitive urban design, 2-4 September 2002, Brisbane, Australia, 2002.

4. Andersen CT, Foster IDL, Pratt CJ. Hydrological Processes 13(4):597-609 (1999)

5. Pratt CJ, Newman AP, Bond PC. Water Science and Technology 39(2):109-30 (1999)

6. Smith D.R. State of Maryland, Department of the Environment, Baltimore, Maryland, 2006.

7. Schlueter W, Jefferies C. Urban Water 4(3):245-53 (2004)

8. Ndon UJ. J Civil and Env. Eng. 7: 288. DOI: 10.4172/2165-784X.1000288 (2017)

9. Sample D.J., and L. Doumar. Permeable Pavement. Publication 426-126 (2013)

10. Suripin dan Kurniani D. Jurnal Media Komunikasi Teknik Sipil, 22 (2), 119-128 (2016) [in Indonesian]

11. Suripin, Kurniani D., and Budieny H. (C) J. of Mathematics and Technology 2010; ISSN: 20780257, No.5, 57-60 (2010)

12. Suda S. and Yamanaka S. Int. Conf. on Concrete Block Paving, 1988, 3rd, Rome, Italy, (1988)

13. Booth DB, Leavitt J. American Planning Ass. J. 65(3):314-25 (1999)

14. Pagotto C, Legret M, Le Cloirec P. Water Research: 34(18):4446-54 (2000)

15. Huang, J.J.; Li, Y.; Niu, S.; Zhou, S.H. Water Sci. Technol. 70, 1740-1745 (2014)

16. Park DG, Sandoval N, Lin W, Kim H, and Yoon-Ho C. (2014). KSCE J. of Civil Eng. 18(2):514-520 (2014) 